\title{
The Values and Significance of the Colonial Steel Railway Bridges of Pakistan
}

\author{
Ayesha Pamela Rogers* and Ghulam Mustafa Baloch \\ Cultural Studies Department, National College of Arts, Lahore, Pakistan \\ * Corresponding author: culturalheritagenca@gmail.com
}

\begin{abstract}
This paper proposes that Civil Engineering Heritage is a distinct form of heritage, related to but differing from Industrial Heritage and a separate field that should be treated independently. The critical element that signifies engineering heritage is ingenium or innovation in development of complex technological responses to physical challenges. Engineering heritage requires specific approaches to its identification, documentation, conservation and management. The important first step of this process is a clear understanding of the values and attributes that contribute to the significance of engineering heritage and must be safeguarded. The example of engineering heritage examined here is the colonial steel railway bridges of Pakistan; three case study bridges are presented and the values and attributes of each are discussed. The paper then identifies a set of shared essential values of this type of engineering heritage that can serve as a basis for value-based conservation and management.
\end{abstract}

KEYWORDS civil engineering, heritage, bridges, colonial, Pakistan, values, innovation

Received June 12, 2017; accepted December 5, 2017.

\section{Introduction}

This paper proposes that Civil Engineering Heritage is a distinct form of heritage, related to but differing from Industrial Heritage, a separate field that should be treated independently from Industrial Heritage. As a result, it requires specific approaches to its identification, documentation, conservation and management, which being a new idea in Pakistan has yet to be clearly understood and elaborated. Even internationally there are only the beginnings of a theoretical framework and body of thought regarding identification of the knowledge, skills and science encoded in engineering structures and objects and a methodology for documentation and analysis to draw out multiple levels of information. The important first step of this process is a clear understanding of the values and attributes that contribute to the significance of engineering heritage and must be safeguarded. The example of engineering heritage examined here is colonial steel railway bridges and the discussion of their values and attributes will be the subject of this paper.

\section{Differences between Industrial and Engineering Heritage}

Engineering is the use of technical knowledge and innovative intellect for creations, which encompass in them values, level of know-how, intents and way of life in those periods. Preservation of civil engineering heritage is a yardstick by which we can measure or trace the course of technology as it has progressed through the ages. Methods of analysis, use of materials, tools, and technology of construction, skill of manpower, intellectual capacity have advanced with time; thus engineering heritage is a witness and record of our previous capabilities and their development (Engineering Heritage Australia 2009).

Defining what makes up the heritage of civil engineering is closely tied to understanding the relationship between civil engineering, industrial heritage and architectural heritage. The industrial heritage reflects the social and working world of the past:

Industrial heritage consists of the remains of industrial culture which are of historical, technological, social, architectural or scientific value. These remains consist of buildings and machinery, workshops, mills and 
factories, mines and sites for processing and refining, warehouses and stores, places where energy is generated, transmitted and used, transport and all its infrastructure, as well as places used for social activities related to industry such as housing, religious worship or education (TICCIH 2003).

An argument is sometimes made that civil engineering works such as railway bridges can be considered as part of 'railway heritage' and are adequately addressed by dealing with them as a part of industrial heritage as defined by TICCIH (2003) above. However, we propose in this paper that the criteria for identifying Civil Engineering Heritage and the values that it embodies justify dealing with it as a separate entity.

The distinctions between architectural, industrial and engineering heritage can be obscure. Take, for example, the railway locomotive maintenance complex at $\mathrm{Mu}$ ghulpura, Lahore, a huge colonial electro-mechanical workshop for the repair and maintenance of railway engines. The complex is constructed on a large area which includes huge steel-trussed sheds for the mechanical and electrical shops, machine foundations, raised platforms, railway lines, water towers, underground hydraulics, water supply networks, surface drainage of the area and other building ancillaries.

The different elements, individually and in groups, can be seen in a variety of ways: individual buildings such as the office blocks and workers' quarters can be seen as architectural heritage; machinery and moving parts may be treated as mechanical engineering heritage. Features such as railway tracks, raised platforms, steel-trussed sheds, machinery and signal boxes can all be viewed as Transport Buildings following the Historic England Guidelines (2011). If we look at the complex as a whole, it fulfils the ICOMOS definition of 'railway heritage', a type of industrial heritage:

The industrial heritage consists of sites, structures, complexes, areas and landscapes as well as the related machinery, objects or documents that provide evidence of past or ongoing industrial processes of production, the extraction of raw materials, their transformation into goods, and the related energy and transport infrastructures. ... It includes both material assets-immovable and movableand intangible dimensions such as technical know-how, the organisation of work and workers, and the complex social and cultural legacy that shaped the life of communities and brought major organisational changes to entire societies and the world in general (ICOMOS 2011).
The doctoral dissertation on which this paper draws (Baloch 2017) proposes that, unlike industrial heritage, railway bridges have somewhat of a readable story to tell about working communities, forces of economic production and social change, but much more to tell about the civil engineering ingenium or innovation that drove and structured the industrial processes of the past. Civil Engineering Heritage very specifically reflects engineering responses to challenges framed by technological limitations of the day: crossing over wild rivers, linking sheer mountain cliffs, boring as well as tunnelling through solid mountains, moving large quantities of water across the landscape and/or controlling its behaviour, creating striking monuments, altering an estuary to accommodate shipping traffic and linking nations with new roads based on historical cultural routes. These are technological responses characterised by ingenium-innovative thought and use of materials which resulted in dramatic changes to the environment and to the social and economic lives of communities while at the same time often creating an aesthetic appeal (Engineers Australia Innovation Taskforce 2012).

We put forward this case for discussion and we propose in this paper to look at the colonial steel railway bridges of Pakistan in this light. The aim is to test whether investigating and conceptualising historical bridges in this way can lead to more nuanced understanding and, ultimately, better conservation and management of Pakistan's steel bridge heritage.

\section{Introduction to the Case Study Bridges}

This paper looks at three case study colonial steel bridges in Pakistan to illustrate the values of this group of heritage resources. They were selected because they show different technical solutions to different environmental challenges and different landscape situations. Figure 1 shows the location of these bridges on the Imperial Gazeteer Atlas of India map of the complete railway network of India dated 1909.

Over the River Indus between Attock Khurd and Khairabad about $80 \mathrm{~km}$ from Peshawar lies the colonial steel railway bridge built in 1883 (Figure 2). The British plans to stop onward expansion of Russia towards Afghanistan and the sub-continent required a rapid system of army movement and deployment, and especially after the first Anglo-Afghan War (1839-1842) it became quite clear that the mighty rivers were a hurdle in rapid transport of army and ammunition in case of any emergency (Bell 1894). 

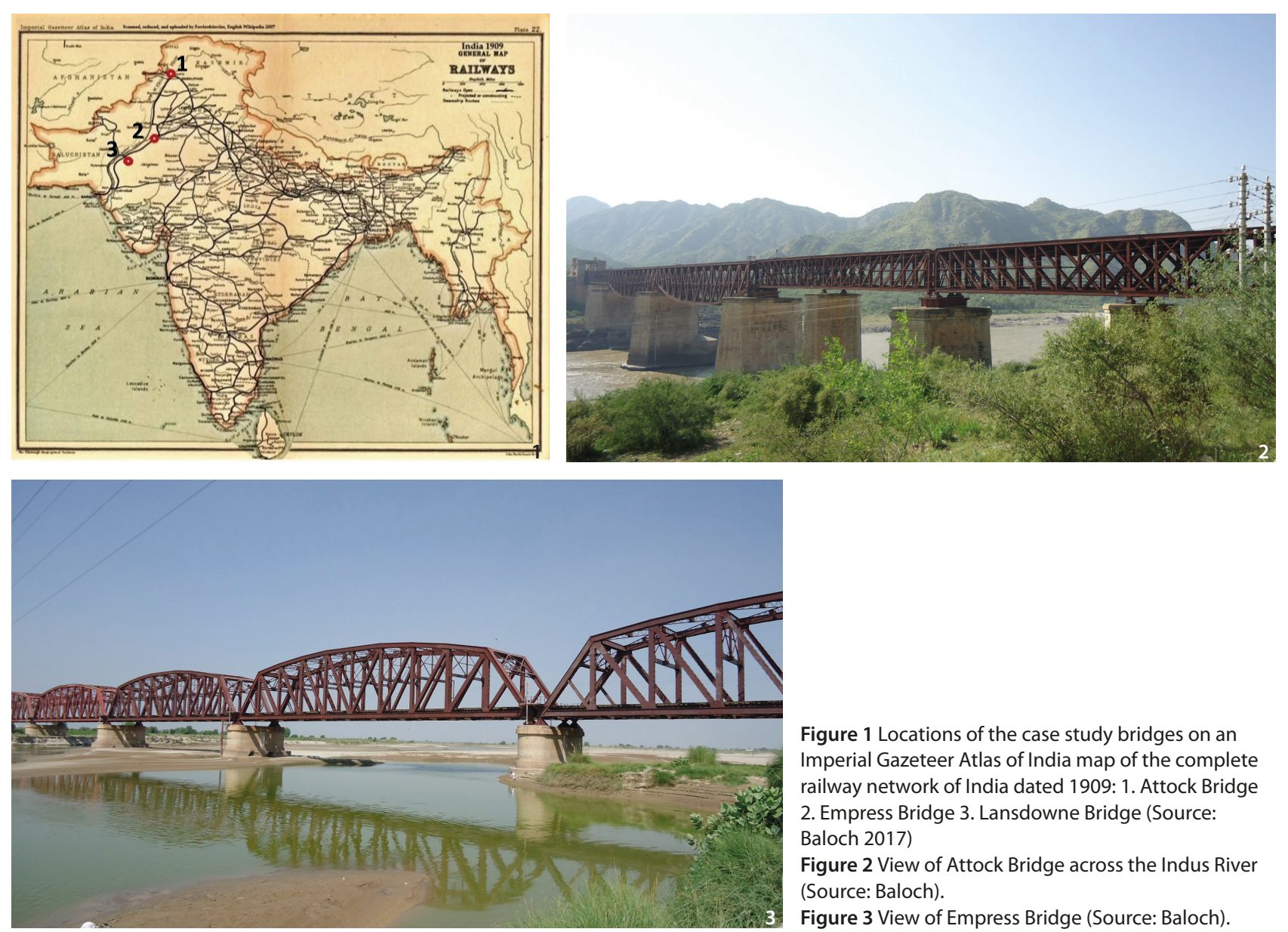

Figure 1 Locations of the case study bridges on an Imperial Gazeteer Atlas of India map of the complete railway network of India dated 1909: 1. Attock Bridge 2. Empress Bridge 3. Lansdowne Bridge (Source: Baloch 2017)

Figure 2 View of Attock Bridge across the Indus River (Source: Baloch).

Figure 3 View of Empress Bridge (Source: Baloch).

Attock Bridge is a double deck bridge carrying a single track railway line over the top deck while the lower deck was used to carry a roadway which has now been restricted for pedestrian traffic only. It is notable for the introduction of a new double-deck design and for the introduction of pre-fabricated steel girders imported from Britain. Evidence is still visible of the historic working platforms where the girders were fabricated and then lifted into place. In this way the bridge, associated so strongly with every invader from Aryans, Greeks, Mughals to the Afghans, all of whom used this specific place to cross the River Indus, is linked to the most modern and hi-tech inventions of that time.

Attock Bridge is an inter-link between two morphologically different terrains: the flat plains of the Punjab and the beginning of the mountainous landscape of the northern areas. It has also acted as a medium to amalgamate two different socio-cultural communities into a common society of shared norms and customs. The impact of this amalgamation can be seen between Nowshera and Hassanabdal, the two cities on either side of the bridge. The bridge in its green setting, the historic Attock Fort in the distance, a Victorian railway station and other historic structures, the winding railway track, the aesthetic view of the bridge and the Indus River itself form a cultural landscape of significance.

On the main railway line from Lahore to Karachi, the Empress Bridge crosses the Sutlej River at the village of Adamwahan (Figure 3). It was built in response to the Great Game to contain Russia within its limits as well as to capture the economic markets and natural resources of Central Asian States, and to stop Russia from reaching the warm waters of Indian Ocean (Bell 1894). The economic and political motivations for the railway and its crossings were closely linked. The Empress Bridge when it opened on June $2^{\text {nd }}, 1878$ was a single line steel bridge consisting of 16 spans (Indus Valley Railway 1879), but it was remodelled to 8 spans and a double railway line bridge in 1929-1930 (Figure 4a, Figure 4b).

This bridge is important as a practical engineering response to a set of severe and limiting constraints; deep silt deposits of the river bottom and a constantly changing river course causing erosion damage to the banks. To meet these constraints the British builders called on 

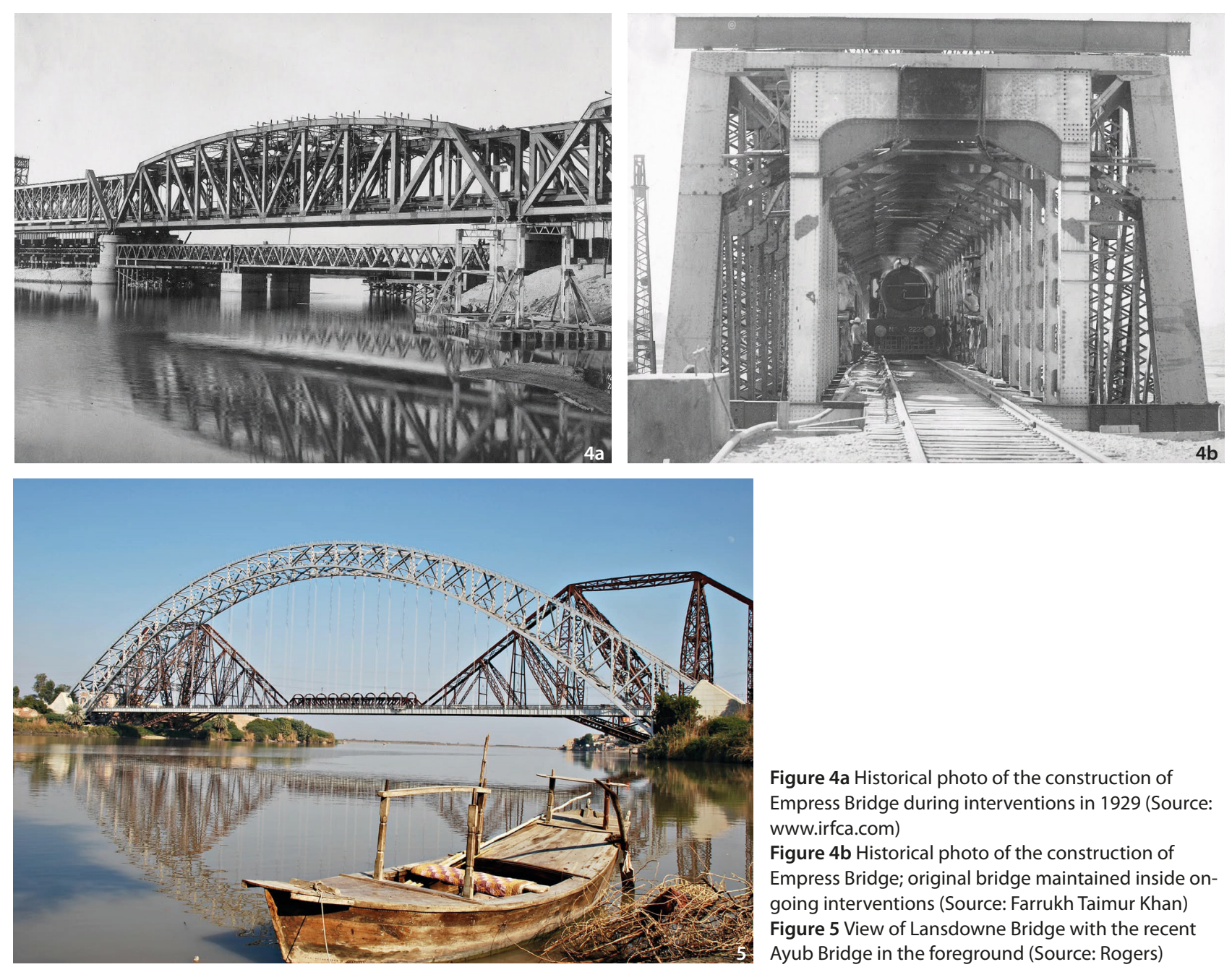

Figure 4a Historical photo of the construction of Empress Bridge during interventions in 1929 (Source: www.irfca.com)

Figure $4 \mathrm{~b}$ Historical photo of the construction of Empress Bridge; original bridge maintained inside ongoing interventions (Source: Farrukh Taimur Khan) Figure 5 View of Lansdowne Bridge with the recent Ayub Bridge in the foreground (Source: Rogers)

engineering expertise, a large local work force and innovative new techniques and approaches.

The landscape in which the bridge is located now comprises agricultural areas, roads and pathways. In this landscape there are numerous hidden river training features related with the bridge such as dykes, groynes, spurs, eight abandoned piers of bridge, sunken wells under them as well as heavy dumps of stone metal to prevent the course of river from meandering and eroding the railway line. Most of these features which were designed and constructed to cope with the changing nature of the Sutlej water flow are now hidden under heavy alluvium deposits, however, a few of them are detectable as they are now re-used as part of roads and pedestrian ways.

Lansdowne Bridge was built during the second Anglo-Afghan war (1878-1880), to facilitate quick military movement and logistics. For military reasons it was decided to extend the railway up to the border of Afghanistan, however, the railway reached only as far as Quetta. The river Indus was not bridged at
Rohri-Sukkur, and the wagons had to be ferried between the two towns on opposite banks which was a slow and cumbersome process. Thus, the work on Lansdowne Bridge was expedited and the bridge was completed in 1889 (Kerr 1995) (Figure 5). Lansdowne Bridge has always played its part in the defense of the country and today it is still monitored by the Pakistan Army and considered a 'sensitive facility'.

Lansdowne Bridge is important due to its technical innovation and use of creative engineering design solutions. It is one of the few rigid cantilever steel truss-bridges ever built and the only mega-steel structure in this part of the world. Use of an early form of steel, rivet connections, assembling and erecting such a huge mass of steel at such a high altitude above flowing water level, and the training and use of local persons displayed the ingenium of those engineers who designed and erected it.

Lansdown Bridge links the two historical towns of Rohri and Sukkur and their populations. As a result, its situation in the landscape, surrounded by ancient as 
well as the living heritage sites, and the important visual impact it creates in the landscape mean that it has very special value and meaning to local residents, visitors and the nation as a whole. In this way it ties together an engineering marvel, a strong sense of place and personal significance in a very singular and unique manner.

\section{Values of Colonial Steel Railway Bridges in Pakistan}

It is the role of heritage conservation and management to retain and interpret the values of a heritage resource:

More and more countries are turning towards a values-led approach to heritage conservation. In this approach, the significance of a heritage property is first established in a participatory process involving all those who have an interest in it. Having defined the significance (statement of significance), this becomes the framework for developing conservation policy and strategy where the condition of the property, rules and regulations, the needs of the communities, etc. are taken into account (UNESCO 2013).

As a group and individually these bridges have special meaning and importance for local communities and the nation as a whole. As Pakistan Railway properties they have retained much of their integrity and authenticity primarily because they have continued to function as river crossings, with changes limited to engineering interventions that form part of their on-going stories.

The colonial steel railway bridges of Pakistan as a group represent the great British Railway enterprise in northwest India; all constructed to service the military campaigns of the Great Game in Afghanistan as well as for the intercontinental trade especially with Europe. The network of rail lines, bridges, stations, sheds and workshops was inherited by Pakistan when independence took place in 1947 and still functions as living evidence of the imperial politics and the British Empire building of the late $19^{\text {th }}$ century (Hurd \& Kerr 2012). The bridges reflect the 'white man's burden' to bring technology and efficiency to the empire along with Christianity, education and bureaucracy, summing up the $19^{\text {th }}$ century belief in mankind's ultimate ability to overcome any obstacle and to make the impossible possible. The ideas encapsulated in these iconic structures had worldwide scientific and architectural application that significantly impacted the economic and social conditions of society in South Asia.

These bridges stand at heritage cluster points, reflecting the continuous use of ancient river crossings. The history of the region is rich with accounts of floating bridges, boat crossings and, in some cases, conquering armies being halted by un-crossable rivers guarded by fortifications and natural barriers. This reflects the fact that bridges are, as stated in the Taipei Declaration for Asian Industrial Heritage (TICCIH 2012), 'part of a comprehensive cultural landscape, either in urban or in rural settings. In addition to the built environment, it strongly reflects the interaction of humans and the land, featuring the characteristics of hetero-topography'.

This cultural landscape value is just one of the many values that comprise the significance of the case study bridges:

Cultural significance is the term that the conservation community has used to encapsulate the multiple values ascribed to objects, buildings, or landscapes. This identification and ordering of values serves as a vehicle to inform decisions about how best to preserve these values in the physical conservation of the object or place. Though the typologies of different scholars and disciplines vary, they each represent a reductionist approach to examining the very complex issue of cultural significance (De La Torre 2002, 8).

These multiple values include: landmark value, aesthetic value, historical value, community or social value and economic value. Although each of these values is important and contributes to the overall significance of the each bridge, they are not specifically related to the nature of these bridges as works of civil engineering.

The critical value that sets Civil Engineering Heritage apart is innovation (Engineering Australia 2012). Each of the steel bridges is a technological response to environmental challenges, employing the newest engineering innovations to deal with hostile conditions, often adopting and adapting local methods to augment the imperial ingenium. The word ingenium comes from the Latin meaning mind or intellect, and old French ingeniere to contrive or innovate; the criteria for Civil Engineering Heritage such as the colonial steel railway bridges of Pakistan hinge on this concept of ingenium or innovation. Each of the case study bridges possesses the value and attributes of this innovation.

\section{Ingenium of Attock Bridge}

The bridge was a final answer to an environmental problem that was addressed in the short term by the building of a temporary boat bridge; the same issues then made the original colonial plan of a tunnel under the Indus 



Figure 6 The innovative pre-fabricated steel girder design of Attock Bridge (Source: Baloch).

Figure 7 Two- tier structure of Attock Bridge (Source: Baloch).

Figure 8a Historical photos of the construction of Attock Bridge in 1900 (Source: Pakistan Railways).

Figure $\mathbf{8 b}$ Historical photos of the construction of Attock Bridge taken during interventions in 1925 (Source: Pakistan Railways).

impossible, even though it came so close to completion that only a small piece of only 200 feet was remaining. It is a fine example of innovative response to failure that characterises Civil Engineering Heritage.

Notable engineering values of Attock Bridge are found in two features of the bridge. Firstly, it is the first example in the Sub-Continent of the use of pre-fabricated steel girder elements (Figure 6) smelted in England according to the then newest technologies and transported via the long journey by sea and by rail to the site. Secondly, the Attock Bridge represented a new concept of design in the subcontinent having a two-tier bridge with railway track on its top booms and a roadway on the lower booms (Figure 7).

When the bridge was modified in 1921 some major strengthening works were carried out while both the railway and the road traffic continued using the bridge; these included stiffening of the central girder spans by attachment of additional curved elements to the outer of the original girders at such an elevated height; the addition of central pillars in the three main 257 feet long girders making them continuous; and the diagnosis of an undermined cavity below the rock-bed over which the central trestle of the bridge was sitting. It was repaired with RCC in which steel rails were used having a total length of about $3 \mathrm{~km}$. These works on a functioning bridge structure (Figure 8a, Figure 8b) exhibited remarkable engineering innovation and ingenuity.

\section{Ingenium of Empress Bridge}

Several important engineering innovations were developed in tandem to enable construction of the Empress Bridge. Its construction was a challenge as it was built on deep alluvium deposits. The problem was how to build foundations for the piers which had to support the heavy dynamic rolling loads of the moving trains. The British used a local Indian technique of sinking deep wells about 

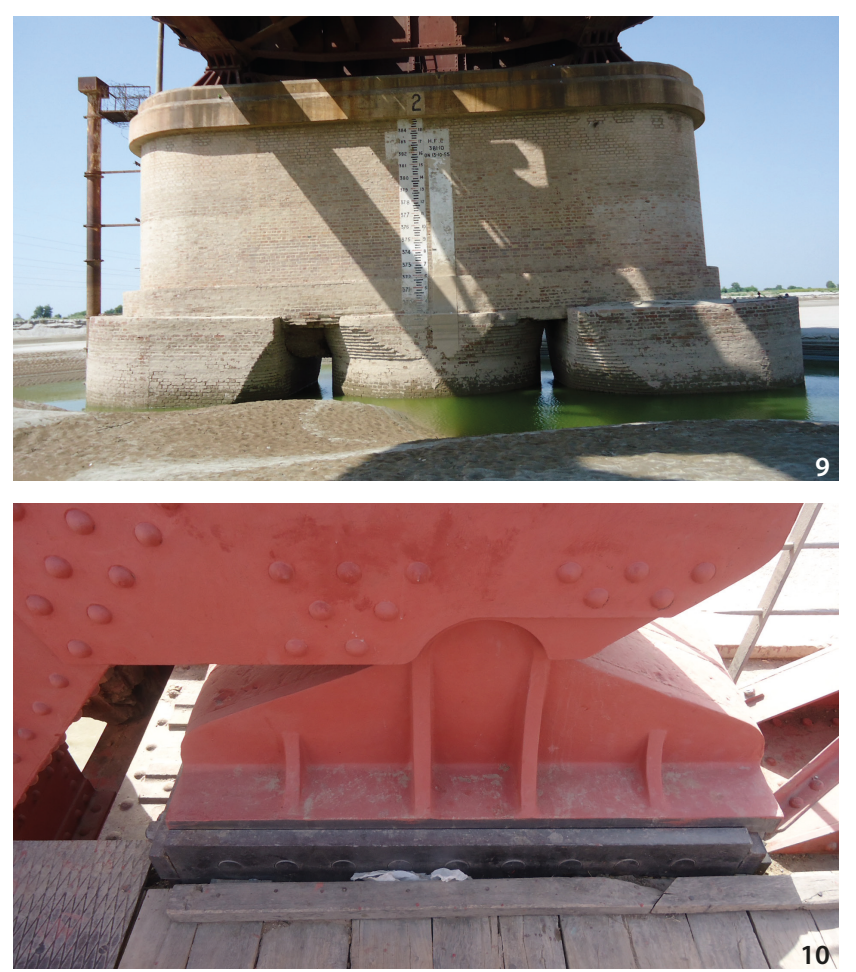

100 feet into the alluvium. Thus was assisted by the French engineer Mr. Gatmell who invented a machine to easily remove the subsoil mud during sinking of the wells. Sir Andrew Clarke appreciating his inventive genius appreciates and expresses:

I cannot leave this part of my theme without mentioning with honour the name of one of ourselves a French engineer, who has been associated with us in this particular work, and to whose skill and inventive genius it is due, that we have been able to accomplish the sinking of the wells with less difficulty, and with much economy of time and money. ... Mr. Gatmell invented a machine which I commend to the attention of those who have not seen it, which is as simple as it is original, and which has removed the hard and gnarled lumps that have been met within the mattress of the Sutlej (Indus Valley Railway 1879).

Mr. J. R. Bell, who was involved with the construction of Empress Bridge, had gained a vast experience of river training works in Punjab, but at the Adamwahan works he was faced with the most difficult type of river embankment. He therefore invented smooth faced, stone-protected guide-banks terminating boldly in impregnable heads standing well out in the river bottom, with no attempt to abut on the bluffs and each bending around, outward, at its upper end to meet the current of the embayment (Figure 9). This technique was afterward
Figure 9 Faced stone-protected guide-banks of Empress Bridge (Source: Baloch).

Figure 10 One of the four hinges supporting the central suspended section of Lansdowne Bridge, attached with four rigid cantilever derricks and cross struts (Source: Rogers).

Figure 11 Lansdowne Bridge's main vertical members of truss-derricks positioned on solid rock (Source: Rogers).

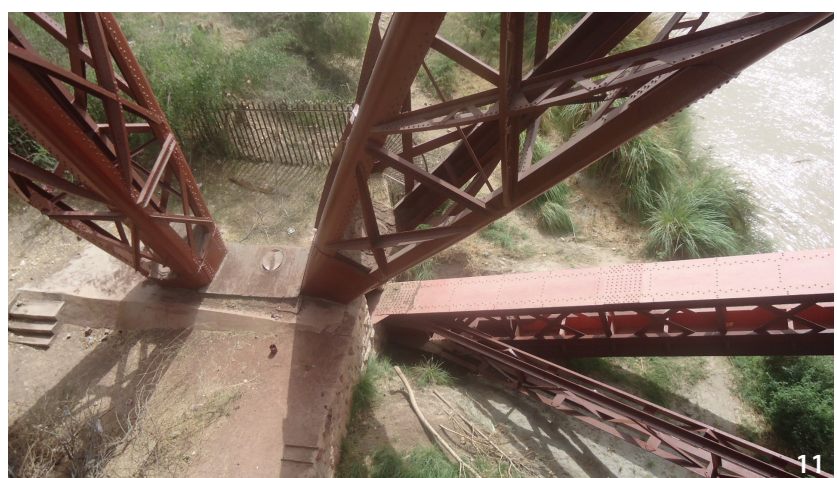

universally adopted in the rivers of the Punjab (Indus Valley Railway 1879).

\section{Ingenium of Lansdown Bridge}

Lansdowne Bridge consists of four independent steel cantilever derricks, deeply buried into the ground with steel grillage, and cropping out approximately 170 feet above the deck, in the form of four trapezium trusses. Two trusses are on either bank of the river, interconnected with each other, and supporting two low height suspension trusses sitting over four steel hinges (Figure 10). The foundations of the four main vertical members of these trussderricks were positioned on solid rock, and they have withheld all the superstructure loads as well as the wear and tear without any settlement or cracking to date (Figure 11). The use of trapezium trusses, grillage footings, and gapping a length of 870 feet without any pier in between was a great challenge at the time. All the members of the bridge, whether tension members or compression, are trusses designed in a unique way that is wider in central part and converging at the two top ends, except the underdeck girders which are fabricated I-sections.

The main parts of the bridge were fabricated in London in the workshop of Westwood Baillie the Contractors, and were assembled and erected at site. According to the original plan, the central suspension part of the bridge was to be assembled at site on interconnected boats in the river approximately 200 feet below the deck and then to 

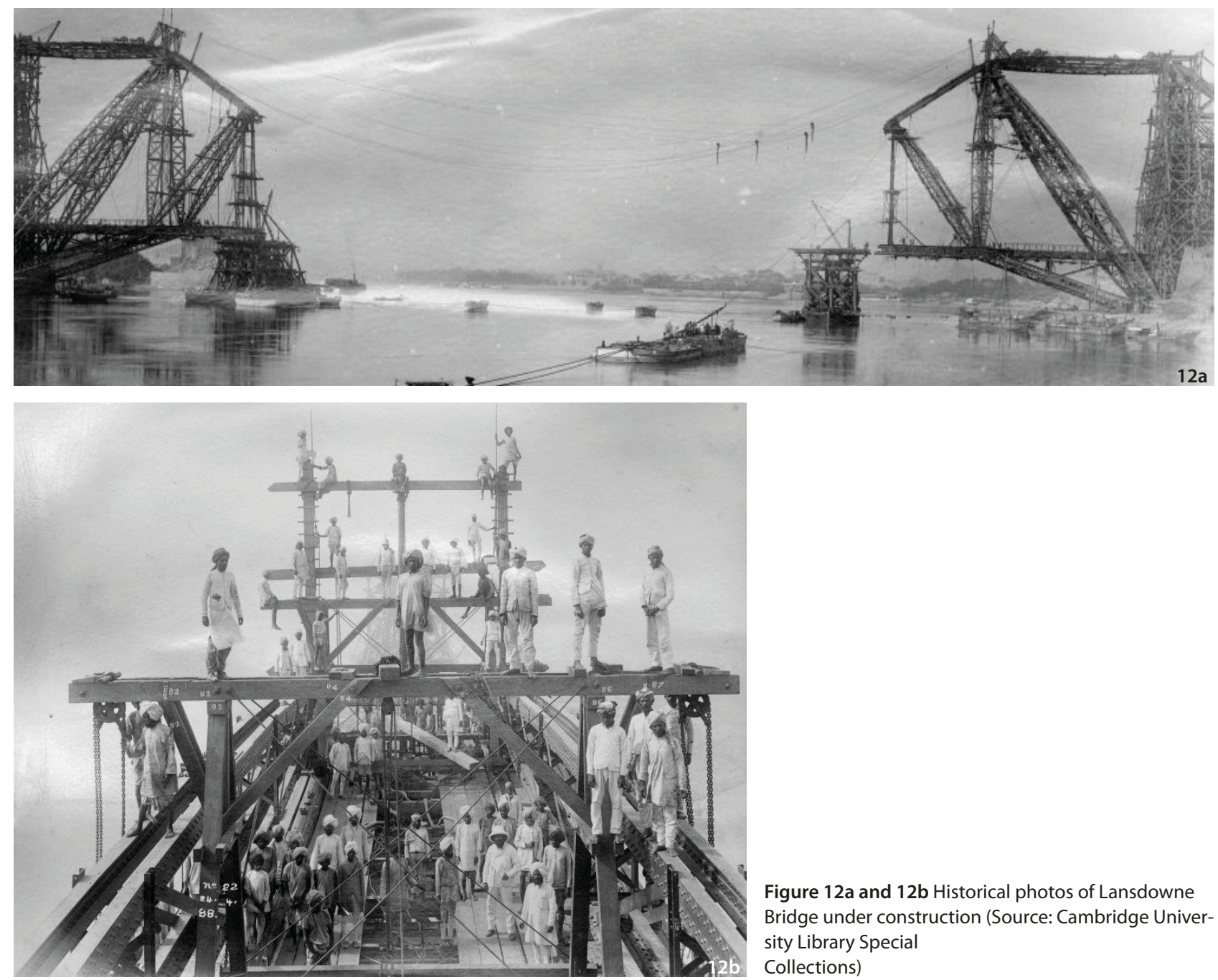

Figure 12a and 12b Historical photos of Lansdowne Bridge under construction (Source: Cambridge University Library Special

Collections)

be lifted up into place. However, due to the high speed of the flowing water of the Indus beneath the deck this plan was changed, and this part of the bridge was assembled in situ on a temporary bridge built for to act as formwork between the cantilevering ends (Figure 12a, Figure 12b). The bridge sits over the four hinges making a link between the cantilever derrick limbs and the suspension bridge parts.

Use of an early form of steel, rivet connections, assembling and erecting such a huge mass of steel at such a high altitude above flowing water level, and the training and use of local persons displayed the ingenium of those engineers, including Sir Alexander Meadows Rendel, who designed and erected it.

\section{Attributes of Ingenium}

It is this quality of technical and engineering innovation as summarised in each of the above bridges which sets historic engineering structures apart from the wider and more generalised idea of industrial heritage.
Ingenium or innovation, as defined by Engineering Australia (2012) involves:

- creating or generating new activities, products, processes and services;

- seeing things from a different perspective or creativity; seeing what everyone sees and thinking what no one else has thought before;

- moving outside the existing paradigms;

- improving existing processes and functions;

- disseminating new activities or ideas.

A core group of character-defining attributes which are related to innovation can be identified as fundamental to preserving the values and significance of Pakistan's colonial steel railway bridges:

a. In situ location. The values of a bridge have direct relationship with the presence of the bridge in its original location and in its intended setting (Figure 13). The reason is that the selection of a site for a bridge was not random, but was an engineering response to specific needs, the suitability of the site and its feasibility 

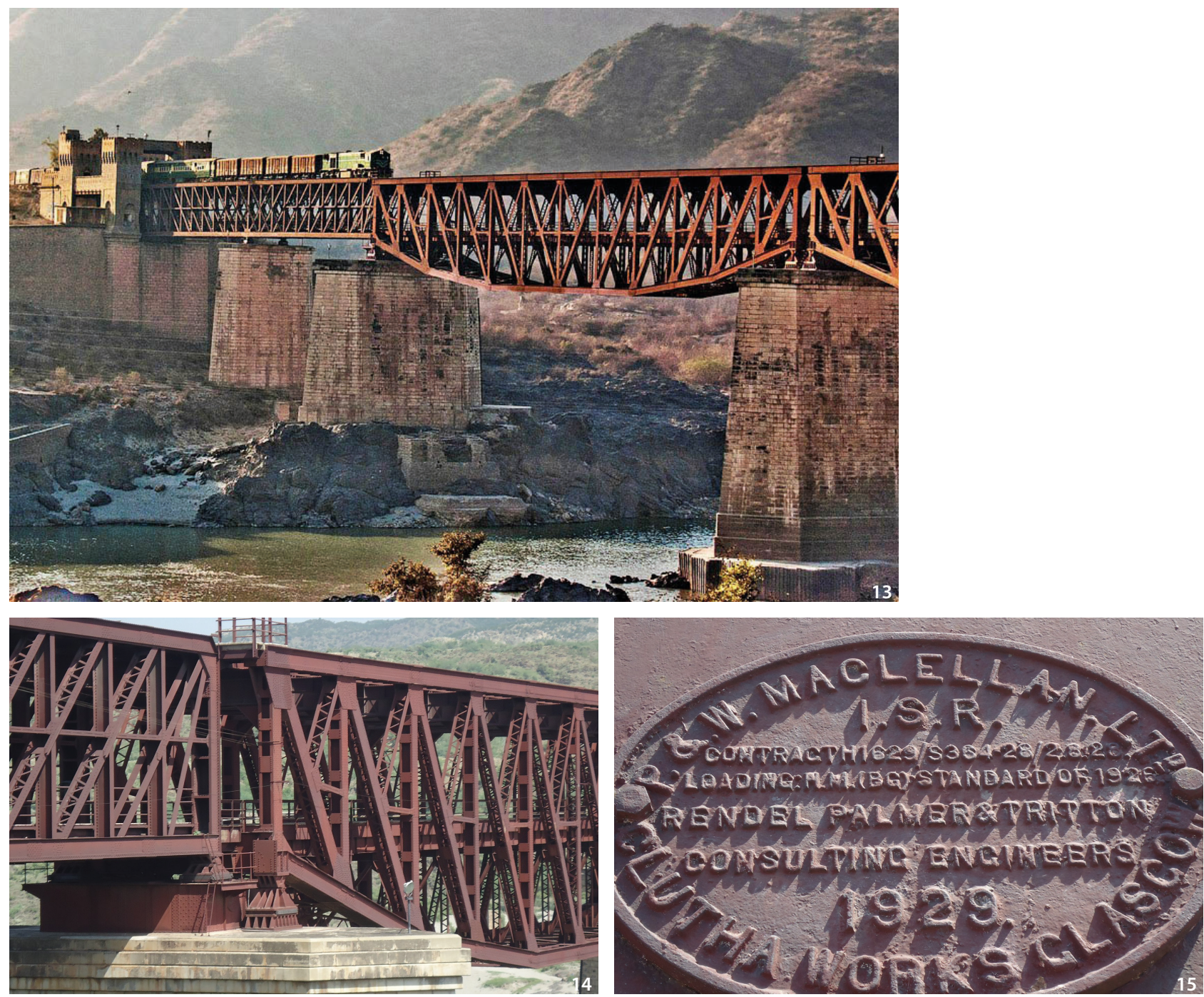

Figure 13 Attock Bridge in its setting on the Indus River (Source: Baloch).

Figure 14 Old and new fabric sections of Attock Bridge: 1880 section on left and 1929 section on right with gap visible between (Source: Baloch). Figure 15 Original plaque on Empress Bridge that documents the date and place of manufacture and the engineers (Source: Baloch).

from technological, geological and socio-economical standpoints.

b. Public access to the bridge. It is important that a bridge be physically accessible to the public even though engineering ingenium is not always easily 'readable'; much of it still remains obscure and hidden and only interpretation and presentation can reveal it to the public. Access therefore means being able to enter the bridge and look at it closely but also it means having access to the information that explains what is being seen.

c. Original fabric. Original fabric must be retained as an essential attribute of civil engineering innovation. The definition of 'original fabric', however, is somewhat different when applied to engineering heritage. It is the nature of engineering to innovate with new and improved technologies, materials and methods and to frequently upgrade and improve physical fabric and elements of a structure. As far as the steel bridges are concerned it is a common phenomenon that the original fabric will need replacement of overstressed members due to fatigue, over stress or over loading because of heavy rolling loads or that widening of the bridge from single to double line may be needed or treatment of settlement of foundations. With changing circumstances and engineering inventiveness, the mix of older and new elements within a bridge is inevitable (Figure 14).

d. Original technical, mechanical and engineering features. The engineering features that provide new adaptations and solutions to challenges and problems are the attributes of the ingenium values of these historic bridges. It is characteristic of engineering works that 
many of the physical features and innovations are not visible, but are hidden from view. Parts of the total works and sometimes the whole of the engineering works remain permanently hidden from human eyes, but they are as important as any visible aspects of engineering structures. This is very much the case with colonial steel bridges. The efforts put in, the techniques used, the innovations of the engineers, and the problems and their solutions are as significant in the history of the engineering heritage as any visible built heritage (Rennison 1996). These may include river training works, temporary tracks and bridges, grillage foundations or the joining and riveting of elements high above the water level-a story embedded in the fabric.

e. Original documentation and subsequent additions to the record. Values are linked with knowledge, and documentation is an important element of the significance of all heritage. Since engineering heritage, such as the colonial steel bridges, incorporates an original concept plus often additional layers and interventions of new technology, it is particularly important that documentation be preserved to explain these stages and the ingenium they represent. The British designers and engineers valued the record as important evidence for future generations, allowing an understanding of all the multiple layers of engineering invention. The historic plaques on the bridges document the designers, makers, dates and locations of all those that contributed to the engineering achievements represented by these bridges (Figure 15).

This set of particular attributes of the ingenium or innovation seen in historic steel railway bridges are critical to their understanding and preserving their values and to a values-based approach to their conservation and management (De La Torre 2002). Some of these aspects are also important for built heritage and industrial heritage; however, as a group they are particular to Civil Engineering Heritage.

\section{Conclusion}

Like the colonial steel railway bridges, Civil Engineering Heritage features complex technological responses to physical challenges; crossing over wild rivers, linking sheer mountain cliffs, boring as well as tunnelling through solid mountains, moving large quantities of water across the landscape and controlling its behaviour, creating striking monuments, altering an estuary to accommodate shipping traffic and linking nations with new roads based on historical cultural routes. These are technological responses characterised by innovative thought and use of materials which resulted in dramatic changes to the environment and to the social and economic lives of communities while at the same time often creating an aesthetic appeal. These are the values that characterise the colonial steel bridges of Pakistan and in a wider sense, the heritage of civil engineering.

The overall aim of this research has been to contribute to our knowledge and understanding of such Civil Engineering Heritage and its significance as an independent field. We hope that it will inspire debate on the definition, role and future management of Civil Engineering Heritage, and bridges in particular, both internationally and within Pakistan. This is the first time that this type of heritage in the form of colonial steel railway bridges have been discussed in Pakistan. Such an impetus is needed to spark local thinking about a theoretical framework and body of thought regarding identification of the knowledge, skills and science encoded in civil engineering structures and objects and a methodology for documentation and analysis to draw out multiple levels of information (Baker 2004).

\section{References}

Australia ICOMOS. 2013. The Burra Charter: The Australian ICOMOS Charter for Places of Cultural Signifcance. Burwood: Australia ICOMOS.

De La Torre, M., ed. 2002. Assessing the Values of Cultural Heritage. Los Angeles: The Getty Conservation Institute.

Baloch, G. M. 2017. "Civil Engineering Heritage: The Colonial Steel Railway Bridges of Pakistan.” Unpublished PhD. diss., National College of Arts.

Bell, H. 1894. Railway Policy of India: With Map of Indian Railway System. Rivington: Percical \& Co. India.

Coulls, A. 1999. Railways as World Heritage Sites. Rome: ICOMOS.

Cox, R. and Gould, M. H. 1998. Civil Engineering Heritage: Ireland. London: Thomas Telford Ltd.

Engineering Heritage Australia. 2009. Engineering Heritage and Conservation Guidelines. Barton: Engineers Australia.

Engineers Australia Innovation Taskforce. 2012. Innovation in Engineering. Melbourne: Engineers Australia.

HAER (Historic American Engineering Record). n.d. HAER No. AZ-57: London Bridge. Washington: HAER.

Historic England. 2011. Designation Listing Selection Guide: Transport Buildings. London: Historic England.

Hurd, J. and I. J. Kerr. 2012. India's Railway History: A Research Handbook. London: Brill. 
ICOMOS. 2005. Xian Declaration on the Conservation of the Setting of Heritage Sites, Structures and Areas. https://www.icomos.org/xian2005/xian-declaration. htm

ICOMOS. 2011. Joint ICOMOS - TICCIH Principles for Conservation of Industrial Heritage sites, Structures, Areas and Landscapes, The Dublin Principles. Paris: ICOMOS. http://www.icomos.org/Paris2011/ GA2011_ICOMOS_TICCIH_joint_principles_EN_ FR_final_20120110.pdf

Indus Valley State Railway. 1879. Administrative Report on the Construction of the Railway from Its Commencement to the Close of the Financial Year 1878-1879. Roorkee, India: Thomson Civil Engineering College Press.

Kerr, I. 1995. Building the Railway of the Raj, 1850-1900. Oxford: Oxford University Press.

McKeel, W. T., A. B. Miller, K. S. Clark, R.W. Saufley, W. H. Bushman, and T. F. Lester. 2006. "Best practices for Rehabilitation and Moving of the Historical Metal Truss Bridges, Final report Virginia Transportation Research Council."

Parks Canada. 2010. Standards and Guidelines for the Conservation of Historical Places in Canada. Ottawa: Government of Canada.

Rennison, R. W. 1996. Civil Engineering Heritage. London: Thomas Telford Publishing.

Smith, L. 2006. The Uses of Heritage. Oxford: Routledge.

TICCIH. 2003. Nizhny Tagil Charter for Industrial Heritage. http://www.icomos.org/18thapril/2006/nizhnytagil-charter-e.pdf

TICCIH. 2012. Taipei Declaration for Asian Industrial Heritage. http://ticcih.org/about/charter/taipei-declaration-for-asian-industrial-heritage/

UNESCO. 2013. Managing Cultural World Heritage. Paris: UNESCO. 